\title{
Evaluation of efficacy and safety of cryotherapy in benign and premalignant cervical lesion
}

\author{
Kishankumar D. Patel ${ }^{1 *}$, Ronak D. Karnavat ${ }^{2}$, Dimple G. Viramgama ${ }^{3}$, Roma K. Dalal ${ }^{4}$
}

Department of Obstetrics and Gynecology, GMERS Medical College and Hospital, Sola, Ahmedabad, Gujarat, India

Received: 22 June 2021

Accepted: 18 July 2021

\section{*Correspondence:}

Dr. Kishankumar D. Patel,

E-mail: kdpate19949@gmail.com

Copyright: ( ) the author(s), publisher and licensee Medip Academy. This is an open-access article distributed under the terms of the Creative Commons Attribution Non-Commercial License, which permits unrestricted non-commercial use, distribution, and reproduction in any medium, provided the original work is properly cited.

\begin{abstract}
Background: Cervical cancer ranks $3^{\text {rd }}$ leading cause of cancer in the world. Cervical erosion is mostly asymptomatic in women but when symptoms like postcoital bleeding and vaginal discharge occur in the presence of cervical erosion, it becomes important to identify whether the erosion is a benign lesion or CIN or cancer by means of PAP smear and Biopsy. Treatment for benign and precancerous lesion can be provided by ablative or excisional methods. Cryotherapy was reliably used to treat cervical lesions.

Methods: Women among 18 to 60 years of age attending outpatient department who had history of chronic discharge per vaginum, postcoital bleeding, dyspareunia, chronic pelvic pain. Patients were divided in two by PAP smear in erosion with inflammatory changes and presence of low grade squamous intraepithelial lesion. Cryotherapy was performed using double-freeze single session procedure. Each patient was followed up at 2, 6 and at 12 weeks. Complications and patients' satisfaction were recorded and compared to calculate cure rate of symptoms, healing of lesion.

Results: The healing efficacy of cryotherapy at $6^{\text {th }}$ and $12^{\text {th }}$ week was $87.8 \%$ and $91.1 \%$ respectively. Cryotherapy had high satisfaction rate. The cure rate was not affected by location of lesion and size of lesion in both inflammation and LSIL.

Conclusions: Cryotherapy is an effective method for treatment of cervical erosion and effectively eliminates symptoms. Patients were highly satisfied. Cryotherapy is cheap, easy, and safe treatment. It is suitable for both hospital and officebased practice.
\end{abstract}

Keywords: Cryotherapy, Low grade squamous intraepithelial lesion

\section{INTRODUCTION}

Cervical lesions irritate women physically, embarrass sexually, scare mentally. Glandular epithelium of cervix has lower cell mediated immunity that creates facilitatory environment for infections as well as carcinogenic implications. ${ }^{1}$ Changes in the cervical epithelium leads to many gynecological symptoms like vaginal discharge, painful coitus, pain in the lower abdomen and abnormal vaginal bleeding. Identifying premalignant and benign diseases of the cervix and selecting an appropriate treatment path can be challenging. Cervical cancer ranks $3^{\text {rd }}$ leading cause of cancer in the world and the $2^{\text {nd }}$ most common cancer among women between 15-44 years of age in world. ${ }^{2}$

Cervical erosion/ectropion (or cervical eversion) is a condition in which the central (endocervical) columnar epithelium protrudes out through the external OS of the cervix and onto the vaginal portion of the cervix, undergoes squamous metaplasia and transforms to stratified squamous epithelium. ${ }^{3}$ Prevalence of cervical erosion is $15-17 \%$ in women. ${ }^{4}$

Cervical erosion is mostly asymptomatic in women but when symptoms such as postcoital bleeding and 
troublesome vaginal discharge occur in the presence of cervical erosion it becomes important to identify promptly whether the erosion is simply a benign lesion or a significant sign of associated infection, CIN or even cancer. Cervical erosion is indistinguishable from early cervical cancer; therefore, further diagnostic studies (e.g., Pap smear, biopsy) must be performed for a differential diagnosis. ${ }^{5}$ Pap smear cytology has remained an important tool in the screening of cervical cancer. ${ }^{6}$

Chronic cervical infection can cause premalignant and malignant changes, $17-20 \%$ association of low grade squamous intraepithelial lesion with cervical erosion. ${ }^{7}$ Treatment for benign and precancerous lesion can be provided by ablative or excisional methods.

Ablative methods include cryotherapy, cold coagulation, laser vaporization and excisional methods include loop electrosurgical excision procedure (LEEP) and laser conization. ${ }^{8,9}$

Cryotherapy was introduced to gynecology in the late 1960s to treat cervical lesions and it is proven to be a reliable treatment modality, with limited side effects and morbidity. ${ }^{10}$

Cryocauterisation machine includes cryoprobes of different sizes, cryogun, $\mathrm{N}_{2} \mathrm{O}$ or $\mathrm{CO}_{2}$ cylinder and connecting tube. The cryotherapy probe tip is applied to the cervix so that it covers the lesion and the cervical tissue is frozen for 3 minutes, thawed for 3 to 5 minutes and then frozen again for 3 minutes. ${ }^{11}$ Cryosurgery is appropriate for use in low resource settings because it is effective (>90\% cure rate), has limited side-effects, does not require electricity, is inexpensive compared to other treatment options and is technically simple to implement. ${ }^{12}$

\section{Aim}

Aim of the study to evaluate the efficacy, safety and patients' satisfaction of cryotherapy in treatment of cervical erosion.

\section{METHODS}

The type of the study was prospective observational and interventional study. The study conducted at the obstetrics and gynecology department, GMERS medical college and hospital, Sola, Ahmedabad. The study conducted from September 2019 to December 2020.

\section{Sample size}

The sample size was 100 (Convenient or purposive sampling method).

\section{Ethical approval}

The study was approved by the institutional ethics committee.

\section{Inclusion criteria}

Women willing to undergo cryotherapy ablation and give consent, age more than 18 years and less than 60 years old, negative for intraepithelial malignancy on pap smear, HIV and VDRL testing negative, women with benign and premalignant cervical erosion, clinically normal looking cervix, without malignant changes were included in the study.

\section{Exclusion criteria}

Patient who did not give consent, lesions extending into endo cervical canal, patient in menses, patient with active bleeding, patient with active infection, pregnant women, women infected with herpes virus were excluded from study.

Women among 18 to 60 years of age attending O.P.D. of the department of obstetrics and gynecology who has history of chronic discharge per vaginum, post-coital bleeding, dyspareunia, chronic pelvic pain during the study period were examined. On examination, pap smear was taken and divided in erosion with inflammatory changes and presence of low grade squamous intra epithelial lesion (LSIL).

Counselling about the procedure and post cryocauterization care and follow up plans were explained in details before the procedure, consent for cryocauterization taken. After consent patient was taken on procedure table and for prevention of vasovagal attack and to relieve pain prophylactic intra muscular atropine and pentazocine were given to all patients before procedure. Procedure was carried out in lithotomy position under all aseptic precautions. Appropriate cryoprobe was taken according to site and size of lesion and gun was attached to nitrous oxide cylinder through gas conveying tube. Cryocauterisation was done using nitrous oxide refrigerant at temperature minus 55 to 58 degrees Celsius with the aim of creating an ice ball with a depth of freeze denoted by a peripheral margin of $2 \mathrm{~mm}$ of frost. The cryoprobe was placed on the lesion, not let it to touch the vaginal wall. The coolant gas was allowed to flow through the channels in the metal tip of the cryoprobe. Cryocauterisation was performed using a double-freeze single session procedure. The double freeze technique involves applying the coolant continuously for a 3-min freeze, followed immediately by a 3 to $5 \mathrm{~min}$ thaw, followed by another 3-min freeze till separation of probe by its own. The patients were asked to refrain from sexual intercourse and were advised not to use tampon for next 23 weeks after cryotherapy to avoid infection and bleeding and to allow re-epithelization of the cry lesion. Prophylactic antibiotics were given for 5 days to all women. Each patient was followed up at 2 weeks, 6 weeks and at 12 weeks. Findings, complications and patients' satisfaction was recorded in study proforma. Data were compared with previous and next subsequent visit to 
calculate cure rate of symptoms, healing of lesion and patients' satisfaction (Figure 1).

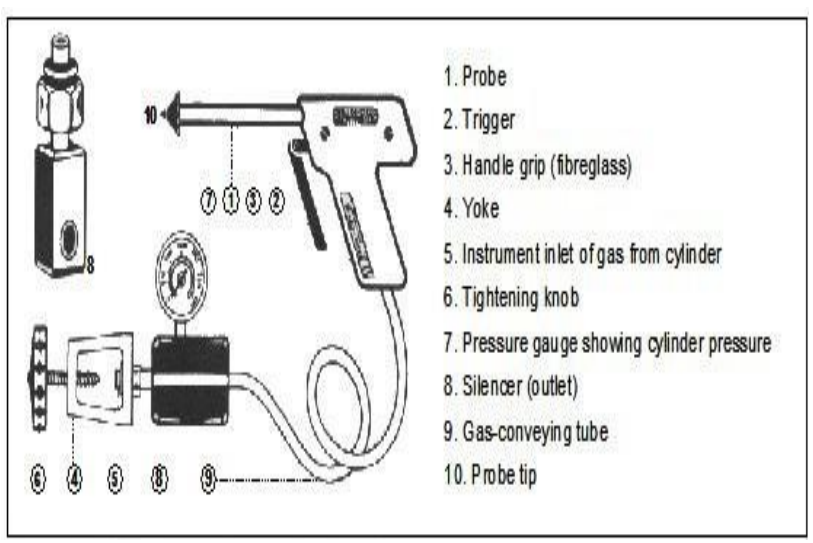

Figure 1: Cryocautery equipment.

\section{Statistical analysis}

Normality of data was tested by non-parametric test, Chisquare and Fischer's exact test were used. A $p<0.05$ was considered statistically significant. The data was entered in
MS excel spreadsheet and analysis was done using Med Calc version 12.1.

\section{RESULTS}

In our study, out of the total patients, $93 \%$ had complaints of abnormal vaginal discharge followed by pelvic pain in $30 \%$, dyspareunia in $24 \%$ and $7 \%$ patients had post coital bleeding. All patients' PAP smears were satisfactory for evaluation. Inflammatory changes were present in $74 \%$ patients and mild dysplasia (low grade squamous intraepithelial lesions, CIN1) in 26\%.

Majority of cases presented with abnormal vaginal discharge in inflammatory group $(94.5 \%)$ and in LSIL (CIN 1) group $(88.4 \%)$. The second most frequent complaint was pelvic pain among the inflammatory group (32.4\%) and dyspareunia (34.6\%) in LSIL (CIN 1) group. Post coital bleeding was present in $5.40 \%$ of the inflammatory group and $11.5 \%$ in LSIL (CIN 1) group. The prevalence of symptoms between two groups was not statistically significant. ( $p>0.05$ ) The main indication for cryo was abnormal vaginal discharge $(93 \%)$. Size of lesion and location of lesion distribution described in Table 1.

Table 1: Evaluation of chief complaints at 2-week, 6 week and 12 weeks.

\begin{tabular}{|c|c|c|c|c|c|c|c|c|c|c|c|}
\hline \multirow{4}{*}{$\begin{array}{l}\text { Chief } \\
\text { complaints }\end{array}$} & \multirow{2}{*}{\multicolumn{8}{|c|}{ Cervical lesions }} & \multirow{2}{*}{\multicolumn{3}{|c|}{ P value }} \\
\hline & \multicolumn{4}{|c|}{ Inflammation } & \multicolumn{2}{|c|}{ LSIL (CIN1) } & & & & & \\
\hline & $\begin{array}{l}\text { Before } \\
\text { cryo }\end{array}$ & $\begin{array}{l}\text { After } \\
\text { cryo at } \\
2 \\
\text { weeks }\end{array}$ & $\begin{array}{l}\text { After } \\
\text { cryo } \\
\text { at } 6 \\
\text { weeks }\end{array}$ & $\begin{array}{l}\text { After } \\
\text { cryo } \\
\text { at } 12 \\
\text { weeks }\end{array}$ & $\begin{array}{l}\text { Before } \\
\text { cryo }\end{array}$ & $\begin{array}{l}\text { After } \\
\text { cryo at } \\
2 \\
\text { weeks }\end{array}$ & $\begin{array}{l}\text { After } \\
\text { cryo at } \\
6 \\
\text { weeks }\end{array}$ & $\begin{array}{l}\text { After } \\
\text { cryo } \\
\text { at } 12 \\
\text { weeks }\end{array}$ & \multirow[t]{2}{*}{$\begin{array}{l}\text { At } 2 \\
\text { weeks }\end{array}$} & \multirow[t]{2}{*}{$\begin{array}{l}\text { At } 6 \\
\text { weeks }\end{array}$} & \multirow[t]{2}{*}{$\begin{array}{l}\text { At } 12 \\
\text { weeks }\end{array}$} \\
\hline & $\begin{array}{l}\mathbf{N} \\
(\%)\end{array}$ & $\begin{array}{l}\mathbf{N} \\
(\%)\end{array}$ & $\mathbf{N}(\%)$ & $\mathbf{N}(\%)$ & $\begin{array}{l}\mathbf{N} \\
(\%)\end{array}$ & $\begin{array}{l}N \\
(\%)\end{array}$ & $\begin{array}{l}N \\
(\%)\end{array}$ & $\mathbf{N}(\%)$ & & & \\
\hline $\begin{array}{l}\text { Abnormal } \\
\text { discharge }\end{array}$ & $\begin{array}{l}70 \\
(94.5)\end{array}$ & $\begin{array}{l}67 \\
(95.7)\end{array}$ & $\begin{array}{l}12 \\
(18.1)\end{array}$ & $\begin{array}{l}5 \\
(7.57)\end{array}$ & $\begin{array}{l}23 \\
(88.46)\end{array}$ & $\begin{array}{l}25 \\
(96.15)\end{array}$ & $\begin{array}{l}4 \\
(16.66)\end{array}$ & $\begin{array}{l}2 \\
(8.33)\end{array}$ & 0.58 & $<0.001$ & $<0.001$ \\
\hline $\begin{array}{l}\text { Abnormal } \\
\text { bleeding }\end{array}$ & $\begin{array}{l}5 \\
(6.75)\end{array}$ & $0(0)$ & $0(0)$ & $0(0)$ & $\begin{array}{l}4 \\
(15.38)\end{array}$ & $\begin{array}{l}1 \\
(3.84)\end{array}$ & $0(0)$ & $0(0)$ & 0.018 & 0.0032 & 0.0032 \\
\hline Dyspareunia & $\begin{array}{l}15 \\
(20.2)\end{array}$ & $0(0)$ & $\begin{array}{l}2 \\
(3.03)\end{array}$ & $0(0)$ & $\begin{array}{l}9 \\
(34.61)\end{array}$ & $0(0)$ & $\begin{array}{l}1 \\
(4.16)\end{array}$ & $0(0)$ & NA & $<0.001$ & $<0.001$ \\
\hline $\begin{array}{l}\text { Post coital } \\
\text { bleeding }\end{array}$ & $\begin{array}{l}4 \\
(5.40)\end{array}$ & $0(0)$ & $0(0)$ & $0(0)$ & $\begin{array}{l}3 \\
(11.53)\end{array}$ & $0(0)$ & $0(0)$ & $0(0)$ & NA & 0.014 & 0.014 \\
\hline Pelvic pain & $\begin{array}{l}24 \\
(32.4)\end{array}$ & $\begin{array}{l}3 \\
(4.28)\end{array}$ & $\begin{array}{l}3 \\
(4.54)\end{array}$ & $\begin{array}{l}1 \\
(1.51)\end{array}$ & $\begin{array}{l}6 \\
(23.07)\end{array}$ & $\begin{array}{l}1 \\
(3.84)\end{array}$ & $\begin{array}{l}2 \\
(8.33)\end{array}$ & $0(0)$ & $<0.001$ & $<0.001$ & $<0.001$ \\
\hline
\end{tabular}

Table 2: Chief complaints, size and location of cervical lesion.

\begin{tabular}{|llll|}
\hline Variables & & Inflammation, $\mathbf{n}(\%)$ & LSIL (CIN 1), $\mathbf{n}(\%)$ \\
& Abnormal vaginal discharge & $70(94.59)$ & $23(88.46)$ \\
\cline { 2 - 4 } Complaints & Abnormal bleeding & $5(6.75)$ & $4(15.38)$ \\
\cline { 2 - 4 } & Dyspareunia & $15(20.27)$ & $9(34.61)$ \\
\cline { 2 - 4 } & Post coital bleeding & $4(5.40)$ & $3(11.53)$ \\
\cline { 2 - 4 } Size (cm) & Pelvic pain & $24(32.43)$ & $6(23.07)$ \\
\cline { 2 - 4 } & $<2$ & $66(89.18)$ & $19(73.07)$ \\
\cline { 2 - 4 } & $>2$ & $08(10.81)$ & $07(26.92)$ \\
\hline
\end{tabular}

Continued. 


\begin{tabular}{|llcc|} 
Variables & & Inflammation, $\mathbf{n}(\%)$ & LSIL (CIN 1), $\mathbf{n}(\%)$ \\
\cline { 2 - 4 } \multirow{3}{*}{ Location } & Anterior lip & $9(12.16)$ & $2(7.69)$ \\
\cline { 2 - 4 } & Circumferential & $39(52.17)$ & $16(61.53)$ \\
\cline { 2 - 4 } & Posterior lip & $26(35.13)$ & $08(30.76)$ \\
\hline
\end{tabular}

Immediately after the procedure, majority had complaints of pain $(21 \%)$, weakness $(11 \%)$ and vomiting $(2 \%)$ while the rest had no complaints. Lesions $>2 \mathrm{~cm}$ size were all cured with cryotherapy (100\%). $89.33 \%$ patients with cervical lesion $<2 \mathrm{~cm}$ was cured with $\mathrm{p}=0.3431$.

The healing efficacy of cryo therapy at $6^{\text {th }}$ week was $87.8 \%$ and $91.1 \%$ at end of $12^{\text {th }}$ week. Statistical analysis showed no difference in healing rate in both groups at $6^{\text {th }}$ week and at $12^{\text {th }}$ week. Cryo cautery is effective in both inflammation as well as LSIL (CIN 1). Statistical analysis showed that cure rate was not affected by location of lesion (p not significant 0.9188 ) and size of lesion (Table 2).

At $2^{\text {nd }}$ week, satisfaction rate was only $11.34 \%$. At $6^{\text {th }}$ week, satisfaction rate was $91.1 \%$ and at $12^{\text {th }}$ week, 92.22\% patients were satisfied. Data analysis showed high satisfaction rate among all patients who underwent cryocauterisation for cervical lesion $(\mathrm{p}<0.001)$ (Figure 2).

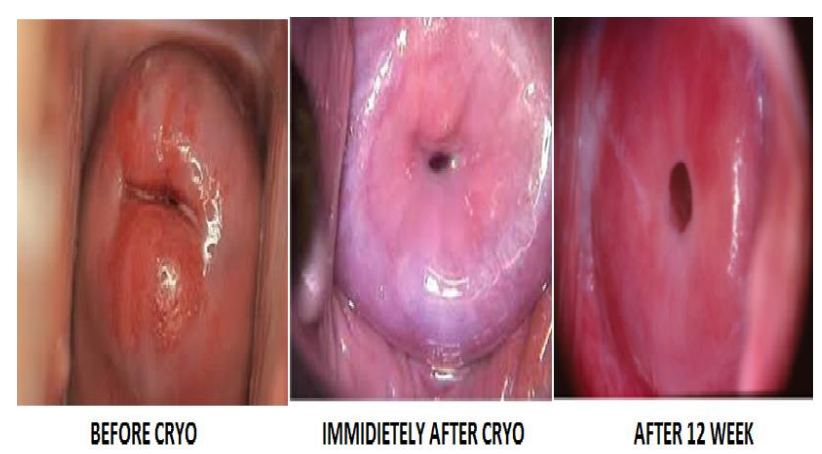

Figure 2: Results of cryotherapy.

\section{DISCUSSION}

In this study $93 \%$ of patients had abnormal white discharge per vaginum followed by pelvic pain in $30 \%$ and dyspareunia in $24 \%$. Similar findings were reported by Katakdhond et al, Jahic et al, Cekmez et al, Gay et al, Mohanty et al, where abnormal white discharge was found in $100 \%, 87 \%, 91.9 \%, 92.6 \%$ and $90 \%$ respectively. ${ }^{4,13-}$ ${ }^{16}$ In another study conducted by Patil et al abnormal vaginal discharge was found in 55\% of patients and this disparity might be because of different prevalence in the institute where the study was conducted. ${ }^{17}$ Hence, abnormal white discharge was the main indication of cryotherapy among all patients.

In this study, the average time of cryotherapy procedure was 15 minutes in most of the patients $(85 \%)$. WHO guidelines for screening and treatment of precancerous lesions for cervical cancer prevention and Katakdhond et al show the same duration of the procedure. ${ }^{4,11}$
In this study, immediate complications included pain in $21 \%$, only $1 \%$ had lateral vaginal wall burn and $92 \%$ had no complaints. Similar findings were observed by Katakdhond et al where pain was found in $17 \%$ immediately after cryo and $80 \%$ had no complications. ${ }^{4}$ Matanyi et al observed that side effects were negligible in 1,248 cervical cryosurgeries. ${ }^{18}$

In a different study with sample size of 52 women, Naud et al (2016) reported pain/cramps (79\%) as the most common adverse event followed by heat sensation $(25 \%) .{ }^{19}$ Viviano et al found that $95.5 \%$ of 110 women studied experienced some degree of pain during therapy when no analgesia was used. ${ }^{20}$

All patients were given injection of pentazocine to relieve pain, similar study conducted by Duncan et al that compared two analgesics (Prilocaine and Felypressin) for pain relief during the procedure concluded that both drugs were efficient in reducing pain. ${ }^{21}$ Overall, the authors concluded that pain is well tolerated and that most patients do not require analgesia.

In this study, out of 100 patients 90 came for follow up after 12 weeks and 10 were lost to follow up. Abnormal vaginal discharge was the most common complaint in this study followed by pelvic pain. All complaints almost subsided after 12weeks of cryotherapy. Abnormal vaginal discharge was present only in $7.77 \%$ and pelvic pain in $1.11 \%$ after 12 weeks of cryocauterisation.

It must be considered that there is no difference in persistence of symptoms between inflammatory group and LSIL (CIN 1) group, as observed by Jahic et al. ${ }^{22}$ Similar findings were also found in a study done by Katakdhond et al and Jahic et al.,22 Mohanty et al recorded that cryotherapy eliminates enhanced vaginal secretion and pain in $98 \% 12$ weeks after the treatment. ${ }^{16}$

The efficacy of present study is $91.9 \%$ and is comparable with most studies. Peck et al, Alvarez et al, Çekmez et al' Jahic et al found the efficacy of $91 \%, 92 \%, 89.05 \%$, 93.05\% respectively. ${ }^{13,14,23,24}$ Whereas Wojtys et al, Guijon et al, Gay et al, Lewis et al, Adefuye et al, Katakdhond et al reported higher efficacy of $95.20 \%, 94.60 \%, 95.20 \%$, $100 \%, 98.2 \%, 96 \%$ respectively. ${ }^{4,1525-28}$ Statistically, in this study, no difference was found in cure rate and location of cervical lesion $(\mathrm{p}<0.05)$. Similar findings observed by Katakdhond et al. ${ }^{4}$

Kwikkel et al reported higher cure rates in small lesions (96.8\%) as compared to large lesions $(75 \%) .{ }^{29}$ Similarly, Ferenczy et al concluded that a higher cure rate was observed for smaller lesions $(<3 \mathrm{~cm}, 92.3 \%)$ than for larger 
lesions (>3 cm, 61.5\%). ${ }^{30}$ Mohanty et al concluded that cryocautery was well tolerated by patients, and had a cure rate of almost $100 \% .^{16}$

This difference in cure rate might be because of a larger probe used for larger lesion after the first freeze. WHO guidelines in 2012 concluded that the cure rate of cryotherapy is $>90 \%$ even in low resource settings. ${ }^{12}$

In this study, satisfaction rate of cryocautery is $92.22 \%$ it is highly recommended to other women by the patients. At the first follow up, satisfaction rates were low (11.34\%) due to persistence of profuse white vaginal discharge for 2-3 weeks post cryotherapy. At $6^{\text {th }}$ weeks, satisfaction rates significantly rose $(\mathrm{p}<0.001)$ up to $91.1 \%$ and at $12^{\text {th }}$ weeks it was $92.22 \%$.

Similarly, Katakdhond et al reported a high satisfaction rate in a sample size of 30 women. ${ }^{4}$ In 2019, Agah et al reported that cryotherapy showed no remarkable side effects and was associated with more satisfaction $(p<0.001){ }^{31}$ Adefuye et al reported that $98.2 \%$ of 220 women believed that the procedure had been as they expected, and $95 \%$ said that they would recommend cryotherapy to other women. ${ }^{21}$ Lewis et al found $100 \%$ satisfaction with cryotherapy among 22 women surveyed at their 3-month follow-up visit. ${ }^{27}$ Phongsavan et al found that all 113 women treated with cryotherapy reported being satisfied or very satisfied with the treatment. ${ }^{32}$

\section{Limitation}

The study was unicentric study. Multicentric study will validate the findings of our study. Large sample size can remove observational bias.

\section{CONCLUSION}

Cryotherapy is effective method for treatment of cervical erosion. Cryotherapy effectively eliminates symptoms like abundant vaginal discharge and pelvic pain. Cryotherapy has minor morbidity till $6^{\text {th }}$ week thereafter nil morbidity after $12^{\text {th }}$ week. Majority $(92.22 \%)$ of the patients were highly satisfied with this mode of therapy. Cryotherapy is a cheap, easy, and safe treatment. It is suitable for both hospital and office-based practice and it can be performed in ambulatory set up.

\section{ACKNOWLEDGMENTS}

Authors would like to thank department of obstetrics and gynecology, GMERS medical college and hospital, Sola, Ahmadabad, Gujarat, for all the kind support and thanks to all the participants for their cooperation.

Funding: No funding sources Conflict of interest: None declared

Ethical approval: The study was approved by the Institutional Ethics Committee

\section{REFERENCES}

1. Louv WC, Austin H, Perlman J, Alexander WJ. Oral contraceptive use and the risk of chlamydial and gonococcal infections. Am J Obstet Gynecol. 1989;160(2):396-402.

2. World Human papilloma virus and related disease report, summary report 2019. Available at https://hpvcentre.net/statistics/reports/XWX.pdf. Accessed on 19 june 2021.

3. Katz: Comprehensive Gynecology, $5^{\text {th }}$ Edition Mosby's Guide to Physical Examination, $7^{\text {th }}$ Edition. 2012:558.

4. Katakdhond S, Samant P. Cryotherapy for cervical lesions: efficacy and patient satisfaction. Int J Reprod Contracept Obstet Gynecol. 2017;6:2331-6.

5. Ugboma HAA, Aburoma HLS. Pap smear: an important screening technique for preventing and detecting cervical cancer. Cont J Med Res. 2010;4:137.

6. Shafi MI. Premalignant and malignant lesions of the cervix. In: Edmonds DK, editor. Dewhurst's Textbook of Obstetrics and Gynaecology, Oxford, UK: Blackwell Publishing. 2007;7.

7. Sarkar PK, Steele PRM. Routine colposcopy prior to treatment of cervical ectopy: Is it worthwhile? J Obstetr Gynaecol. 1996;16:2:96-7.

8. Wright TC, Richart RM, Ferenczy A. Electrosurgery for HPV related diseases of the lower genital tract: a practical handbook for diagnosis and treatment by loop electrosurgical excision and fulguration procedures. Quebec7 Arthur Vision Incorporated. 1992.

9. Sankaranarayanan R. Effectiveness, safety and acceptability of 'see and treat' with cryotherapy by nurses in a cervical screening study in India. Brit $\mathrm{j}$ cancer. 2007;96(5):738-43.

10. Gage AA, Baust J. Mechanisms of tissue injury in cryosurgery. Cryobiology. 1998;37(3):171-86.

11. WHO Guidelines: Use of Cryotherapy for Cervical Intraepithelial Neoplasia. Geneva: World Health Organization; 2011. Available at: https://www.who.int/reproductivehealth/publications /cancers/9789241502856/en/. Accessed on 20 June 2021.

12. WHO: Cryosurgical Equipment for the Treatment of Precancerous Cervical Lesions and Prevention of Cervical Cancer: WHO Technical Specifications. Geneva, Switzerland, WHO, 2012. Available at: https://www.who.int/reproductivehealth/publications /cancers/9789241504560/en/ accessed on 20 June 2021.

13. Jahic M. Cryotherapy of Erosion of Cervix and Low Grade Squamous Intraepithelial Lesion. Mater Sociomed. 2018;30(4):294-6.

14. Çekmez Y, Şanlıkan F, Göçmen A, Vural A, Türkmen SB. Is Cryotherapy Friend or Foe for Symptomatic Cervical Ectopy? Med Princ Pract. 2016;25:8-11.

15. Gay C, Riehl C, Ramanah R, Desmoulin G, Violaine B. Cryotherapy in the management of symptomatic 
cervical ectopy. Gynecol Obstet Fertil. 2006;34(3):214-23.

16. Mohanty KC, Rand RJ, Berry B. Cryotherapy in the management of cervical ectopy. Genitourin Med. 1985;61(5):335-7.

17. Patil P, Sharma P. Colposcopic evaluation of cervical erosion in symptomatic women. Int $\mathbf{J}$ Reprod Contracept Obstet Gynecol. 2017;6:2207-11.

18. Matányi S. Side effects and complications of cervical cryotherapy. Acta Chir Hung. 1992-1993;33(12):157-62.

19. Naud PS et al: Efficacy, safety, and acceptability of thermo-coagulationfor treatment of cervical intraepithelial neoplasia in a hospital setting in Brazil. Int J Gynaecol Obstet. 2016;133:351-4.

20. Viviano M, Kenfack B, Catarino R. Feasibility of thermocoagulation in a screen-and-treat approach for the treatment of cervical precancerous lesions in subSaharan Africa. BMC Womens Health. 2017;17:2.

21. Duncan ID, McKinley CA, Pinion SB, Wilson SM. A double-blind, randomized, placebo-controlled trial of prilocaine and felypressin (Citanest and Octapressin) for the relief of pain associated with cervical biopsy and treatment with the Semm coagulator. J Low Genit Tract Dis. 2005;9(3):171-5.

22. Jahic M. Cryotherapy of Erosion of Cervix and Low Grade Squamous Intraepithelial Lesion. Mater Sociomed. 2018;30(4):294-296.

23. Peck JE. Cryosurgery for benign cervical lesions. Br Med J. 1974;2(5912):198-9.

24. Alvarez Bravo A.Cryosurgery of the uterine cervix. Our experience in 3,184 cases. Ginecol Obstet Mex. 1991;59:105-11.

25. Wojtyś A, Zdebski Z. Effects of low-temperature treatment of pathologic changes of the cervix uteri. Ginekol Pol. 1989;60(5):276-9.
26. Guijon F, Paraskevas M, McNicol P. Human papillomavirus infection and the size and grade of cervical intraepithelial neoplastic lesions associated with failure of therapy. Int $\mathrm{J}$ Gynaecol Obstet. 1993;42(2):137-42.

27. Lewis KD, Sellors JW, Dawa A, Tsu VD, Kidula NA. Report on a cryotherapy service for women with cervical intraepithelial neoplasia in a district hospital in western Kenya. Afr Health Sci. 2011;11(3):370-6.

28. Adefuye PO, Dada OA, Adefuye BO, Shorunmu TO, Akinyemi BO, Idowu-Ajiboye BO. Feasibility, acceptability, and effectiveness of visual inspection of the cervix with acetic acid and cryotherapy for dysplasia in Nigeria. Int $\mathbf{J}$ Gynaecol Obstet. 2015;129(1):62-6.

29. Kwikkel HJ, Helmerhorst TJ, Bezemer PD, Quaak MJ, Stolk JG. Laser or cryotherapy for cervical intraepithelial neoplasia: a randomized study to compare efficacy and side effects. Gynecol Oncol. 1985;22(1):23-31.

30. Ferenczy A. Comparison of cryo- and carbon dioxide laser therapy for cervical intraepithelial neoplasia. Obstet Gynecol. 1985;66(6):793-8.

31. Agah J, Sharifzadeh M, Hosseinzadeh A. Cryotherapy as a Method for Relieving Symptoms of Cervical Ectopy: A Randomized Clinical Trial. Oman Med J. 2019;34(4):322-326.

32. Phongsavan K, Phengsavanh A, Wahlström R, Marions L. Safety, feasibility, and acceptability of visual inspection with acetic acid and immediate treatment with cryotherapy in rural Laos. Int $\mathrm{J}$ Gynaecol Obstet. 2011;114(3):268-72.

Cite this article as: Patel KD, Karnavat RD, Viramgama DG, Dalal RK. Evaluation of efficacy and safety of cryotherapy in benign and premalignant cervical lesion. Int J Reprod Contracept Obstet Gynecol 2021;10:3066-71. 